\section{B A Institute of \\ YK Business Administration \\ 六下 \\ Karachi \\ Leadership and Ideas for Tomorrow}

Business Review

Volume 7 Issue 1 January-June 2012

$1-1-2012$

\title{
The effects of employees' perceptions of performance appraisal process of readymade garments industries in Bangladesh : An empirical study
}

Dhasro Miah

North South University, Bangladesh

A.K.M. Mominul Haque Talukder

North South University, Bangladesh

Follow this and additional works at: https://ir.iba.edu.pk/businessreview

Part of the Business Administration, Management, and Operations Commons, Fashion Business Commons, and the Performance Management Commons

\section{(c) (1)}

This work is licensed under a Creative Commons Attribution 4.0 International License.

\section{Recommended Citation}

Miah, D., \& Talukder, A. (2012). The effects of employees' perceptions of performance appraisal process of readymade garments industries in Bangladesh : An empirical study. Business Review, 7(1), 94-105. Retrieved from https://doi.org/10.54784/1990-6587.1304 


\title{
ARTICLE
}

\section{The Effects of Employees' Perceptions of Performance Appraisal Process of Readymade Garments Industries in Bangladesh : An Empirical Study}

\author{
MD. Khasro Miah \\ North South University, Bangladesh \\ A.K.M. Mominul Haque Talukder \\ North South University, Bangladesh
}

\begin{abstract}
This study investigates the effects of employees' perception of performance appraisal process on organizational commitment, job satisfaction, and employee retention in readymade garments sectors. Results indicate a significant positive relationship between employee retention with performance appraisal process. Conversely, organizational commitment indicates a negative but not significant relationship with performance appraisal process. Study recommends that Readymade Garments sector requires fair performance appraisal system to enhance employee's job satisfaction and organizational commitment. It also asserts employers positive perception to employees regarding the performance appraisal implications. Finally, the study commends that collaboration between employers and employees is essential to build an effective performance appraisal process.
\end{abstract}

Key words : Readymade Garments, Performance Appraisal Process, Organizational Climate, Job Satisfaction, Employee Retention

\section{Introduction}

Performance appraisal is frequently used as an administrative decision such as employee promotion or transfer. This process is inherent in the very contextual fabric of organizations, and therefore needs more careful examination (Mintzberg, 1983), particularly in the light of the limited research done on perceptions of performance appraisal process (Drory and Romm, 1990; Parker, Dipboye, and Jackson, 1992). Ferris, Russ, and Fandt (1989) developed a conceptualization of organizational process perceptions, which has served as the impetus for some empirical testing of portions of the model. There are several indications that performance review may occur less frequently in the view of the subordinates. Meyer et al., (1965) found that in many companies, interviews are not actually conducted unless strong control procedures insuring their occurrence have been established.

Landy and Trumbo (1980) reported experience with numerous companies in which available performance ratings were not presented to employees, partly because of logistic difficulties for one supervisor interviewing all subordinates, and partly out of superiors' feeling that the ratings served no real use. 
A few reviews of the related literature suggest that most of the study on Readymade Garments (RMG) industries, organizational culture includes performance appraisal policies as part of organizational political views. However, a limited research has focused on performance appraisal politics exclusively (Bhattacharya and Rahman, 1999). Hence, the current study would enhance the literature on performance appraisal policy and its organizational outcomes in garment sector. The study would help the entire garment sector to gain a further understanding of their employees' perception of performance appraisal process, job satisfaction, organizational commitment and employees' retention in context of garments employees.

\section{Literature Review}

Readymade garments' firms need to deal with issues of performance appraisal process (PAP) in order to remain competitive in the global market. The above information leads us to develop an empirical study to explore the current situation of RMG sector's organizational climate. A number of international scholars discussed 'performance appraisal' as a discrete, formal, organizationally sanctioned event, usually not occurring more frequently than once or twice a year, which has clearly stated performance dimensions and/or criteria that are used in the evaluation process (DeNisi and Pritchard, 2006).

'Performance management' is a broad set of activities aimed at improving employee performance (DeNisi and Pritchard, 2006). Although performance appraisal information provides input for the performance management process, performance management focuses on ways to motivate employees to improve their performance. Again, the goal of the performance management process is performance improvement, initially at the level of the individual employee, and ultimately to the organization. The ultimate goal of performance appraisal could be to provide information that will best enable managers to improve employee performance. Thus, ideally, the performance appraisal provides information to help managers manage in such a way that employee performance improves.

\section{Perception of Performance Appraisal Process}

Dowling et al., (1999) stated that international performance management is a strategic HRM process that enables the MNCs to evaluate and continuously improve individuals, subsidiary units and corporate performance against clearly defined, pre-set objectives that are directly linked to international strategy. Performance appraisal is considered as one of the several key elements of performance management. Cardy and Dobbins (1994) define performance appraisal as the process of identifying, observing, measuring and developing human resources in organizations. Performance is typically judged subjectively because performance in many jobs is not amenable to objective assessment (Ferris and Judge, 1991). In the performance appraisal context, distributive justice refers to the fairness of the evaluation received, whereas procedural justice refers to the fairness of the process used in determining the evaluation (Greenberg, 1986). Although both types of fairness perceptions are important, fairness in performance appraisal has been conceptualized largely in relation to due process (Taylor et al., 1995).

An effective performance appraisal system (PAS) encourages individual performance by reinforcing organizational objectives. This is accomplished by establishing personal performance objectives that are congruent with overall organizational goals. In turn then, encouraging individual performance through performance appraisal promotes overall organizational performance (Katsanis, Laurin, and Pitta, 1996). Performance appraisal is an important process for influencing both the extrinsic and intrinsic motivations of employees and their attitudes towards companies. Given the pervasive nature of process in performance appraisal processes, it is important to examine its impact on employees' attitudes and behaviors. Because people's attitudes and behaviors are determined by their perceptions of 
reality (Lewin, 1936), this study focused on the effects of perceptions of performance appraisal process.

\section{Job Satisfaction}

Job satisfaction is one criterion for establishing the health of an organization; rendering effective services largely depends on the human source (Fitzgerald et al., 1994) and job satisfaction experienced by employees will affect the quality of service they render. The impact of other variables on efficiency, such as infrastructures and internal relationships, should also be recognized. Job satisfaction has been defined as a positive emotional state resulting from the pleasure a worker derives from the job (Locke, 1976) and as the affective and cognitive attitudes held by an employee about various aspects of their work (Wong et al., 1998); the latter implying that satisfaction is related to the component facets rather than the whole job, which is consistent with Spector's (1997) view.

Ferris, Russ, and Fandt (1989) developed a model of perceptions of organizational process. In this model, they demonstrated that organizational process of any kind is associated with job anxiety, job satisfaction, job involvement, and organizational withdrawal. Mani (2002) argued that supervisors' fairness in performance appraisal is a predictor of employees' satisfaction with supervision. Ferris and his colleagues added that employees' satisfaction with supervision, in turn, leads to their satisfaction with the job. Nye and Witt (1993) revealed those employees' perceptions of workplace process such as an unfair appraisal is negatively correlated with job satisfaction. The above given information leads following hypothesis:

Hypothesis 1: There is a significant relationship between perception of performance appraisal process and employees' job satisfaction in perspective of garments industries.

\section{Organizational Commitment}

Organizations must increase their commitment and dedication to employees if they want employee commitment, dedication and hard work. A number of previous researches in South Asia reveal that employers can make an impact on how their employees feel by taking positive steps to create a work environment that indicates, by action, that the employee is valued. Employees that have a positive attitude about the organization that they work for, perceiving that their work contributions are valued and that their organization cares about them are more willing and likely to work harder (Miah et.al., 2003; Miah and Bird, 2007). Mowday, Porter and Steers (1979) indicated that employee' perceptions of organizational process of any kind influence employees' organizational commitment. Parker, Dipboye, and Jackson (1995), in their study on some government employees revealed that employees' perceptions of unfairness in reward decisions such as performance appraisal reduce employees' organizational commitment. They suggested that such lower commitment would lead to employees' lower involvement with their work and employees' turnover intention. Therefore, the second hypothesis is as follows.

Hypothesis 2: There is a significant relationship between perception of performance appraisal process and employees' organizational commitment in context of garments industries.

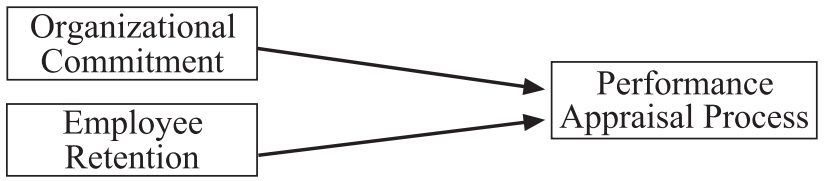

Figure 1: Conceptual framework of research variables and their relationship 


\section{Employee Retention}

Randall, Cropanzano, Borman, and Birjuin (1999) asserted that employees' perceptions of any kind of workplace process including performance appraisal process lead employees to think about quitting. Poon (2004) noted that when employees perceive that managers are trying to realize their political motives in performance rating, employees will develop turnover intention. Turnover intention refers to employees' thoughts of quitting their present job. Because people tend to view organizational process as undesirable, they are unlikely to want to remain permanently in a workplace they perceive to be politically charged. Employees may choose to withdraw physically or psychologically. One physical form of withdrawal is to quit the job. Not all employees, however, have the immediate luxury of such an option. The likely short-term option for those with less job mobility is psychological withdrawal, such as thinking about quitting (Poon, 2003). Heightened levels of organizational political demands have been suggested as being predictive of employees' intention to quit their job (Ferris et al., 1989). Several authors reported that perceived organizational process is significantly related to turnover intention (Randall et al., 1999). Therefore, the third hypothesis is:

Hypothesis 3: There is a significant relationship between perception of performance appraisal process and employees' retention in context of garments industries.

\section{Methodology}

\section{Demography}

From the responded questionnaires, simple descriptive statistics were calculated to describe the distribution of the data. The respondents consisted of $6 \%$ from small size (50-200) 70\% from medium size (201-1000); 24\% large size (1001-5000) garment industries.

Table 1: Demographic information of the study variables

\begin{tabular}{|l|c|c|}
\hline \multicolumn{1}{|c|}{ Variables } & Frequency & Percentage (\%) \\
\hline Company Size & $50-200$ & 96 \\
$201-1000$ & 98 & 70 \\
$1001-5000$ & 23 & 24 \\
\hline Education & & \\
High School & 11 & 8 \\
Bachelor & 70 & 50 \\
Masters & 59 & 42 \\
\hline Work Experience & & \\
1-10 yrs & 67 & 48 \\
$11-20$ yrs & 73 & 52 \\
\hline Marital Status & & \\
Married & 95 & 68 \\
Single & 45 & 32 \\
\hline Gender & 50 & 36 \\
Male & 90 & 64 \\
Female & \\
\hline
\end{tabular}


For the work experience 1 to 10 years $48 \%$ and $11-20$ years $52 \%$. In terms of marital status $68 \%$ were married and $32 \%$ single respondents covered in this study. Participants were $36 \%$ male and $64 \%$ female in various garments industries. In terms of educational qualifications participants were $8 \%$ high school (11), 50\% Bachelor degree (70) and $42 \%$ Master degree (59) respectively.

\section{Design}

Convenience sampling method has been employed to select the participants. For this study, readymade garment (RMG) industries in Bangladesh were selected as sample. A mail survey was used in 2008-2009 for data collection. The key respondents were manager's human resource, accounting, factory, administration officers and executives of respective garment industries. With regard to questionnaire mailing, 56 surveys were undeliverable because of missing address or had moved to unknown locations. Deducting the undeliverable from the original 600 mailed, the valid mailing was 544 surveys, from which 360 responses were received. Of the surveys completed and returned, only 144 were usable. The effective response rate was approximately $40 \%$. According to Aaker, Kumar and Day (2001) the response rate for a mail survey, without an appropriate follow up procedure, is less than $20 \%$, thus the response rate of this study is considered acceptable. All the questions in the survey questionnaire are of 5-point Likert Scale ranging from 1 (Strongly Disagree) to 5 (Strongly Agree). All the participants were given a letter, attached to the questionnaire, from the researcher explaining the context of the research.

\section{Measurements of Variables}

\begin{tabular}{|l|l|}
\hline \multicolumn{1}{|c|}{ Measured Variables } & \multicolumn{1}{c|}{ Sources } \\
\hline Performance Appraisal Process (PAP) & $\begin{array}{l}\text { Is operationally defined by the Questionnaire } \\
\text { of Political Considerations in Performance } \\
\text { Appraisal (QPCPA) developed by Tziner, } \\
\text { Latham, Price and Haccoun (1996). }\end{array}$ \\
\hline Organizational Commitment (OC) & $\begin{array}{l}\text { Is operationally defined by Mowday, Steers } \\
\text { \& Porter, (1979). }\end{array}$ \\
\hline Employee Retention (ER) & $\begin{array}{l}\text { Is adapted from definitions developed by } \\
\text { Carmeli (2003) and Chiu and Francesco (2003). }\end{array}$ \\
\hline Job Satisfaction (JS) & $\begin{array}{l}\text { Is adapted from definitions developed by } \\
\text { Miah } \text { et al., 2003. }\end{array}$ \\
\hline
\end{tabular}

\section{Findings}

\section{Factor Analysis}

Employees' perceptions of performance appraisal process: For the purpose of identification of the basic dimensions for performance appraisal process there were five variables cited in Poon (2004). Cronbach's alpha for this scale was found to be 97 (See Table 2).

Employees' job satisfaction: For the job satisfaction measure, participants indicated the extent to which they were satisfied with their present job, all things considered. For the purpose of identification of the basic dimension for Job Satisfaction in this research there were six variables. Cronbachs alpha for this scale was found to be .99 (See Table 2). 
Employees' organizational commitment: It will be measured by a several-item short form of the OCQ developed by Mowday et al., (1979). Each item is cast on a 5-point Likert scale. Cronbach's alpha for this scale was found to be .98 .

Employees' Retention Rate in the present Organization: A 6-item (5-point likert) scale by combining three items from Carmeli (2003) and three items from Chiu and Francesco (2003) has been used in this research. Cronbach's alpha for this scale was found to be .86 .

Descriptive coefficient means and standard deviations of all the constructs are displayed in Table 3. Mean scores have been computed by equally weighting the mean scores of all the items. The mean score for perception of appraisal process is 3.83 indicating that the existence of appraisal process is perceived to be higher in garment industries. The mean value for organizational commitment is 2.95 , which implies the employees of garment industries are loyal to their organization. The mean score for job satisfaction is 3.18 which mean the employees of garment industries have higher level of job satisfaction. The mean value for retention rate of the employees is 4.01. It implies that that garment employees intend to stay in their current organization is also higher. A correlation analysis was conducted on all variables to explore the relationship between them $(n=140)$. The result denotes that performance appraisal is significantly positively correlated with job satisfaction $(\mathrm{r}=.26$, $\mathrm{p}<.01)$. It is negatively correlated with the organizational commitment $(r=-.14, p<n . s)$. Although, it is positively correlated with the employee retention $(r=.94, p<.001)$. Table 4 shows the result of regression analyses for exploring determinants of performance appraisal process and job satisfaction, organizational commitment, and employee retention.

Table 2: Summary results of principal component analysis

\begin{tabular}{|c|c|c|c|c|}
\hline Variables & F1 & F2 & F3 & F4 \\
\hline Factor 1: Performance Appraisal Process $(a=.97)$ & & & & \\
\hline $\begin{array}{l}\text { 9. Performance appraisal has begun to give way } \\
\text { to seemingly more objective }\end{array}$ & .93 & & & \\
\hline $\begin{array}{l}\text { 8. Merit based performance appraisal and productivity } \\
\text { do these effect }\end{array}$ & .93 & & & \\
\hline $\begin{array}{l}\text { 7. Selective disenchantment with performance appraisal } \\
\text { associated with specific organization levels \& functional } \\
\text { responsibilities, then perhaps attempts to improve } \\
\text { performance appraisal success can be more effective }\end{array}$ & .92 & & & \\
\hline 1. Avoid ratings that have negative consequences for employees & .91 & & & \\
\hline $\begin{array}{l}\text { 5. Does the process appraisal system provide employee with } \\
\text { substantial input into the appraisal process? }\end{array}$ & .90 & & & \\
\hline 3. Avoid low ratings to avoid written record of poor performance & .34 & & & \\
\hline $\begin{array}{l}\text { 6. The congruence of task types and performance appraisal } \\
\text { formats will lead to higher performance appraisal effectiveness }\end{array}$ & .32 & & & \\
\hline 4. Give equivalent ratings to avoid resentment and rivalries & .27 & & & \\
\hline 2. Inflate ratings to maximize rewards to employees & .23 & & & \\
\hline
\end{tabular}




\section{\begin{tabular}{|l} 
Variables \\
\hline Factor 2: Job Satisfaction $(\mathrm{a}=.99)$
\end{tabular}}

4. I want to work in this company until retirement

2. I am proud to work in this company

5. The company is a good place

1. I am very satisfied with my job

3. I want to help this company for better performance

6. Generally, I enjoy my work

Factor 3: Organizational Commitment (á=.98)

2. I talk up this organization to my friends as a great organization to work for

3. I would take my type of job assignment in order to keep working for this organization

5. This organization really inspires the very best in me in the way of job performance

4. I find that my values and organization's values are very similar

1. I am willing to put in a great deal of effort beyond that normally expected in order to help this organization be successful

8. I am satisfied working in this organization

6. I really care about the fate of this organization

7. I am extremely glad that I chose this organization to work for over others I was considering at the time I joined

\section{Factor 4: Employee Retention $(a=.86)$}

4. In the last few months, I have not seriously thought about looking for new job

2. I am not searching for an alternative to the organization

3. I want to stay in this organization

5. Presently, I am not actively searching for other job

6. I do not intend to leave the organization in the near future

1. I do not think about leaving the organization

Eigen value 
It is found that as predicted in the hypothesis 1 , there is no significant relationship between perception of performance appraisal process and employees' job satisfaction in context of garment industries. From the table 4 it is also found that $(\mathrm{B}=.95, p<.001)$ employee retention in the organization affects positively performance appraisal process which supports the hypothesis 2 .

Table 3: Descriptive statistics and correlation coefficients of variables

\begin{tabular}{|l|c|c|c|c|c|c|c|c|c|c|}
\hline \multicolumn{1}{|c|}{ Variables } & Mean & SD & $\mathbf{1}$ & $\mathbf{2}$ & $\mathbf{3}$ & $\mathbf{4}$ & $\mathbf{5}$ & $\mathbf{6}$ & $\mathbf{7}$ & $\mathbf{8}$ \\
\hline Performance & & & & & & & & & & \\
Appraisal Process & 3.83 & 1.03 & & & & & & & & \\
Job Satisfaction & 3.18 & 1.33 & $.26^{* *}$ & & & & & & & \\
Organizational & & & & & & & & & & \\
Commitment & 2.95 & 1.44 & -.14 & $-.46^{* *}$ & & & & & & \\
Employee & & & & & & & & & & \\
Retention & 4.01 & 1.95 & $.94 * *$ & $.28^{* *}$ & $-.17 *$ & & & & & \\
Size of the & & & & & & & & & & \\
Company & 2.85 & 1.11 & -.06 & -.04 & .05 & -.04 & & & & \\
Education & 3.30 & .75 & -.01 & .01 & .11 & -.07 & -.02 & & & \\
Work Experience & 2.61 & .89 & .02 & -.04 & -.07 & -.00 & .05 & .13 & & \\
Marital Status & 1.32 & .46 & .02 & .06 & -.02 & .04 & .08 & .07 & .05 & \\
Gender & 1.64 & .48 & .13 & .14 & -.12 & $.18^{*}$ & .10 & -.02 & -.02 & .06 \\
\hline
\end{tabular}

$N=140 ; * * * p<.001, * * p<.01, * p<.05$

Again, the regression table demonstrates that organizational commitment has produced positive impact $(B=.02, p<\mathrm{n} . \mathrm{s})$ which supports the hypothesis 3 partially but not significantly making the relationship between perception of performance appraisal process and organizational commitment in garment industries.

Table 4: Regression results affecting performance appraisal process

\begin{tabular}{|l|c|c|c|c|c|}
\hline \multirow{2}{*}{\multicolumn{1}{|c|}{ Variables }} & \multicolumn{2}{c|}{$\begin{array}{c}\text { Unstandardized } \\
\text { Coefficient }\end{array}$} & \multicolumn{2}{c|}{$\begin{array}{c}\text { Standardized } \\
\text { Coefficient }\end{array}$} & \\
\cline { 2 - 5 } & $\mathbf{B}$ & S. Error & $\boldsymbol{B}$ & $\mathbf{t}$ & \multirow{2}{*}{ Sig. } \\
\hline Job Satisfaction & .00 & .03 & .01 & .16 & .86 \\
Organizational Commitment & .02 & .02 & .02 & .65 & .51 \\
Employee Retention & 1.02 & .03 & .95 & .32 & .00 \\
Size of the company & -.01 & .02 & -.01 & -.06 & .54 \\
Education & .06 & .04 & .04 & 1.60 & .09 \\
Work Experience & .02 & .03 & .02 & .83 & .40 \\
Marital Status & -.04 & .06 & -.02 & -.78 & .43 \\
Gender & -.09 & .06 & -.04 & -1.45 & .14 \\
F & 370 & & & & \\
R & .94 & & & & \\
$\mathrm{R}^{2}$ & .89 & & & & \\
Adjusted R ${ }^{2}$ & .88 & & & & \\
\hline
\end{tabular}




\section{Discussions}

No such strong and significant relationship has been found in order to support the proposed hypotheses. However, the overall findings of the study commend that the factors such as employee retention and job satisfaction need to be addressed for better employees' work outcomes in the overall garment sector. The appraisal system could be modified and monitored on a regular basis to encourage positive feedback from the employees. The Human Resource could come forward to mitigate the problems pertaining to performance appraisal while mitigating the communication gaps between the organization and the employees. Readymade garments sector, expected to compete and grow, must shed old thinking and shift from a paternalistic approach designed to obtain loyalty to an engaging approach aimed squarely at employee commitment. Negative feedback following performance appraisal not only fails to motivate the loyal employees, but can also cause them to perform worse over time. Only employees having a high degree of self-esteem appear to be stimulated by criticism to improve their performance.

A few studies have done so far on perception of performance appraisal in the context of readymade garment (Akhter, 2008; Uddin and Hassan, 2007). Hence, the present study would investigate the relationship between employees' perception of performance appraisal process, job satisfaction, employee retention, and organizational commitment and their holistic effect in the garments industries. Several authors (Boundreau, 1991; Jones and Wright, 1992; Kleiner, 1990) revealed that high performance management system enhances retention of quality employees and while encouraging the non-performers to leave the organization. From the study it has been proved that performance appraisal process in organizations is perceived to emanate from the behavior of supervisors, co-workers, and from organizational policies and practices. Therefore, criticism needs to be discussed in a constructive rather than a destructive way.

\section{Conclusions}

Research shows that employees are likely to feel more satisfied with their appraisal result if they have the chance to talk freely and discuss their performance. It is more likely that such employees will be better able to meet future performance goals. Employees need to know how well they are doing at their jobs and where they could improve. Performance appraisal researchers are now at the crossroads of making significant strides in achieving a better understanding of the appraisal process. When paying attention to careful performance appraisal system, its planning and proper techniques to be used, performance appraisal might be perceived not only as an irreplaceable tool for recognizing and rewarding good performance. There are several things, however, that can be kept in mind when preparing and doing performance appraisal for readymade garments. According to this study, an analogy might illustrate how the coordination between researchers and practitioners can be envisioned. The study would help making a proper application of performance appraisal process to enhance positive organizational outcomes. This will encourage further research and provide useful guidelines for creating a new avenue to pursue better understanding and constructive performance appraisal process in the garment sector of Bangladesh. The study further suggests that Human Resource Department and appraisers alike could consider performance appraisal mainly as a means for development and motivation, not only a guideline for remuneration and promotion and/or demotion. 


\section{References}

Aaker, DA., Kumar, V., \& Day, G.S. (2001). Marketing Research, 7th ed. John Wiley and Sons New York, NY

Akhter, N. (2008). Performance Appraisal of the Employees of Local Private Manufacturing Enterprises in Bangladesh. Business Review, Journal of Business Studies, 6(1), 75-82.

Bhattacharya, D., \& Rahman, M. (1999). Female Employment under Export propelled Industrialization: Prospects for Internalising Global Opportunities in the Bangladesh Apparel Sector, UNRISD Occasional Paper No. 10, UNRISD, and Geneva.

Boudreau, J. W. (1991). Utility analysis for decisions in human resource management. In M. D. Dunnette \& L. M. Hough (Eds.), Handbook of industrial and organizational psychology Palo Alto, CA: Consulting Psychologists Press.

Cardy, R.L., \& Dobbins, G.H., (1994). Performance Appraisal: Alterative Perspectives, 1st Ed., South-Western

Carmeli, A. (2003). The relationship between emotional intelligence and work attitudes, behavior and outcomes: An examination among senior managers. Journal of Managerial Psychology, 18(8), 788-813.

Chiu, R. K., \& Francesco, A. M. (2003). Dispositional traits and turnover intention: Examining the mediating role of job satisfaction and affective commitment. International Journal of Manpower, 24(3), 284-298.

DeNisi, A.S., \& Pritchard, R.D. (2006). Performance Appraisal, Performance Management, and Improving Individual Performance: A Motivational Framework, Management and Organization Review, 2(2), 253-277

Dowling P.J., Welchet, D.E., \& Schuler, R.S. (1999). International Dimensions of Human Resource Management, 3rd edn. Cincinnati OH: South-Western.

Drory, A., \& Romm, T. (1990). The definition of organizational politics: A review. Human Relations, 43(2), 1133-1154.

Ferris, G.R., \& Judge, T.A. (1991). Personnel/human resources management: a political influence perspective. Journal of Management, 17, 447-488.

Ferris, G.R., Russ, G.S., \& Fandt, P.M. (1989). Politics in Organizations. In Giacalone, R.A., Rosenfeld, P. (Eds), Impression Management in the Organization, Erlbaum, Hillsdale, NJ, 143-70.

Fitzgerald, M. P., Sagaria, M. A. D., \& Nelson, B. (1994). Career patterns of athletic directors: Challenging the conventional wisdom. Journal of Sport Management, 8, 14-26.

Greenberg, J. (1986). Determinants of perceived fairness of performance evaluations. Journal of Applied Psychology, 71(2), 340-342.

Jones, G. R., \& Wright, P. M. (1992). An economic approach to conceptualising the utility of human resource management practices. In K. M. Rowland \& G. R.Ferris (Eds.), Research in personnel and human resources management. Greenwich, CT: JAI Press. 
Katsanis, L. P., Laurin, J.P., \& Pitta D. A. (1996). How Should Product Managers Be Evaluated In Emerging Product Management Systems? Journal of Product and Brand Management, 5(6), 3-20.

Kleiner, M.M. (1990). The role of industrial relations in firm performance. In J.A. Fossum \& J. Mattson (Eds.), Employee and Labor Relations: 4.23-4.43 Washington, DC: BNA Press.

Landy, F.J., \& Trumbo, D.A. (1980). Psychology of Work Behaviour. 2nd Ed., Dorsey Press, US II.

Lewin, K. (1936). Principles of Topological Psychology, McGraw-Hill, New York, NY.Effects of performance appraisal politics on job satisfaction and turnover intention. Personnel Review, 33(3), 322-334.

Locke, E. (1976). The Nature and Causes of Job Satisfaction. Handbook of Industrial/ Organizational Psychology Edited by M.D. Dunnette (Chicago: Rand McNally, 1976): 901-969.

Mani, B. G. (2002). Performance appraisal systems, productivity, and motivation: A case study. Public Personnel Management, 31(2), 141-159.

Meyer, H. H., Kay, E., \& French, J. R. P. (1965). Split roles in performance appraisal. Harvard Business Review, 43, 123-29.

Miah, M. K., Wakabayashi, M., \& Takeuchi, N. (2003). Cross-cultural comparisons of HRM styles: based on Japanese companies, Japanese subsidiaries in Bangladesh and Bangladeshi companies. Journal of Global Business Review, 4(1), 77-98.

Miah, M.K., \& Bird, A. (2007). The impact of culture on HRM styles and firm performance: evidence from Japanese parents, Japanese subsidiaries/joint ventures and South Asian local companies. The International Journal of Human Resource Management, 18(5), 908-923.

Mintzberg, H. (1983). Power in and around Organizations. Englewood Cliffs, NJ: PrenticeHall.

Mowday, R. T., Porter, L. W., \& Steers, R. M. (1979). Measurement of organizational commitment. Journal of Vocational Behavior, 25(4), 224-247.

Nye, L. G. \& Witt, L. A. (1993). Dimensionality and construct validity of the perceptions of organizational politics scale (POPS). Educational and Psychological Measurement, $53,821-829$.

Parker, C. P., Dipboye, R. L., \& Jackson, S. (1992). L Politics perceptions: An investigation of antecedents and consequences. Paper presented at the Annual Meeting of the Society for Industrial and Organizational Psychology, Montreal.

Parker, C. P., Dipboye, R.L., \& Jackson, S.L. (1995). Perceptions of organizational politics: An investigation of antecedents and consequences. Journal of Management, 21, 891-912

Poon, J. M. L. (2003). Situational antecedents and outcomes of organizational politics perceptions. Journal of Managerial Psychology, 18(1/2), 138-155. 
Poon, J. M. L. (2004). Effects of performance appraisal politics on job satisfaction and turnover intention. Personnel Review, 33(3), 322-334.

Randall, M.L., Cropanzano, R., Bormann, C.A., \& Birjulin, A. (1999). Organizational politics and organizational support as predictors of work attitudes, job performance, and organizational citizenship behavior. Journal of Organizational Behavior, 20(3), 159-74.

Spector, P. (1997). Job Satisfaction: Application, Assessment, Cause and Consequences. Sage Publications, London.

Taylor, M.S., Tracy, K.B., Renard, M.K., Harrison, J.K., \& Carroll, S.J. (1995). Due process in performance appraisal: a quasi-experiment in procedural justice. Administrative Science Quarterly, 40, 495-523.

Tziner, A., Latham, G. P., Price, B. C., \& Haccoun, R. (1996). Development and Validation of a Questionnaire for Measuring Perceived Political Considerations in Performance Appraisal. Journal of Organizational Behavior, 17(2), 179-190.

Uddin, M., Habib, M., \& Hassan, M. (2007). Human resource management practices in power generation organizations of Bangladesh: A comparative study of public and privatesector, Journal of Business Studies, 3(2), 129-144.

Wong, C.S., Hui, C., \& Law, K.S. (1998). A longitudinal study of the job perception-job satisfaction relationship: a test of the three alternative specifications. Journal of Occupational and Organizational Psychology, 71(2), 127-46.

I get bored very soon with an existing business.

I need to do new and different things, things not done by anyone else. 